\title{
TECHNOLOGIES OF QUALITY MANAGEMENT TRAINING FOR FUTURE TEACHERS TO PROFESSIONAL ACTIVITY
}

\author{
ТЕХНОЛОГІЇ УПРАВЛІННЯ ЯКІСТЮ ПІДГОТОВКИ \\ МАЙБУТНІХ УЧИТЕЛІВ ДО ПРОФЕСІЙНОЇ ДІЯЛЬНОСТІ
}

\author{
Mykola KONDRASHOV, \\ Candidate of Pedagogical Sciences, \\ Doctoral Candidate \\ Микола КОНДРАШОВ, \\ кандидат педагогічних наук, \\ докторант \\ https://orcid.org/0000-0002-3411-2209 \\ kondrashovmm@ukr.net \\ Cherkassy National University \\ Черкаський національний \\ Cherkassy, Ukraine \\ університет імені Богдана \\ Хмельницького \\ Original manuscript received: October 01, 2019 \\ Revised manuscript accepted: December 11, 2019
}

\begin{abstract}
The article reveals the essence of technological process of teaching process and technology of quality management of the training of future teachers for professional activity in the conditions of university education. In this context, the definition of technology of quality management of students' training is described, the types of technologies characterized, their structure and content, the mechanism of their use in the management of the educational process, achievement of the predicted results as indicators of the quality of professional activity.

The analysis of scientific literature confirms the need for a new quality management system for the training of future teachers for professional activity, which ensures the use of various technologies for managing the teaching process in the context of university education. Purpose disclosure of the essence and components of quality management technology for the training of future teachers for professional activities in the context of university education is considered in the article.The technology of quality management of the training of future teachers for professional activity is considered as a system of theoretical positions and recommendations that make it possible to effectively organize the managerial actions of the teacher in planning, designing, implementing and analyzing objectively necessary steps of cognitive activity of students, guaranteeing the successful achievement of projected results in the form of experience creative pedagogical activity.

In the quality management system, the training of future teachers for professional work is important for their mastery of management technology, its components (the process of teaching activity, the sequence of actions, methods, operations, procedures, tools). Quality management technology for the training of future teachers for successful professional activities is a system of interaction between the teacher and students in planning, organizing and implementing educational and selfeducation processes aimed at mastering the chosen profession, forming readiness for successful activity and improving the quality of university education. In practice, the training of future teachers for professional use uses a variety of technologies for ICV 2018: 77.58


Серія: Педагогічні науки. - Вип.3. - Бердянськ : БДПУ, 2019. - 453 с.

managing the learning process, including: documentation-integrative, integral, cognitive, management decision-making, prognostic-monitoring technology management, etc. Learning management technologies provide the conditions for future teachers to acquire the ability to use theoretical knowledge as an instrument of practical actions and management experience, which positively influences the quality of their preparation for independent professional work.

Key words: management, technology teaching process, management technology, quality of professional activity.

Вступ. Сучасне суспільство вимагає підвищення вимог до якості підготовки майбутніх учителів до професійної діяльності. Воно пропонує нові шляхи розв'язання актуальних педагогічних проблем, оновлення змісту, форм, методів, засобів, системи навчальної діяльності, забезпечення практико-технологічної її спрямованості, ефективне використання резервів і ресурсів реформування системі університетської освіти. Суттєво зростає значення технологічного чинника управління якістю підготовки майбутніх учителів до професійної діяльності, без якого учасниками освітнього процесу не будуть достатньою мірою зрозумілі технології управління та їх зв'язок 3 цілями і якістю підготовки до професійної діяльності. Майбутнім учителям важливо зрозуміти й усвідоміти роль та можливості технологій управління в досягненні цілі й завдань професійної підготовки, її якості й результативності.

Проблема ефективного управління освітніми закладами, підготовкою кадрів досліджувалася багатьма вченими. Унаслідок усебічного осмислення наукової літератури зафіксовано низку підходів до розв'язання проблеми підготовки фахівців до організації педагогічного процесу в різних типах освітніх закладів (Т. Бабкіна, І. Зязюн, Н. Ничкало, Н. Остапенко, Л. Хомич та інші). Педагогічний аспект проблеми знайшов висвітлення в роботах: Н. Гузій, Н. Кічук, Л. Кондрашової, З. Курлянд, О. Мороза та ін. Теоретичні засади управління освітою розроблено Ю. Конаржевським, В. Крижком, М. Масловим, М. Поташником, С. Сисоєвою. Управлінському аспекту організації педагогічного процесу й підготовки кваліфікованих кадрів присвячені роботи Т. Десятова, Г. Дмитренка Г. Ельникової, Л. Калініної, А.Кучерявого, А. Новикова, О. Орлова, Г. Попова, А. Харьківської, К. Яресько та ін.

Особливий інтерес становлять праці зарубіжних науковців, які досліджували проблему управління освітою, підготовки кваліфікованих кадрів: С. Бернарда, Р. Дафта, Н. Еванса, Дж. Керола, Р. Левіса, Р. Макклендона, Г. Мініцберга, Періса Дж. Скатта, А. Тума, А. Файоля. Віддаючи належне проведеним дослідженням, слід відзначити, що не менш значуща сьогодні проблема технологізації управління якістю підготовки майбутніх учителів до професійної діяльності в умовах університетської освіти, але процес технологізації управління нею практично не досліджено. Особливості можливостей його реалізації в освітньому процесі потребує більш детального дослідження, зумовлюють необхідність самоорганізації студентів, пошуку інноваційних технологій управління в системі університетської освіти. Мета статті - розкриття суті 
та характеристика складнтків різних видів технології управління якістю підготовки майбутніх учителів до професійної діяльності в умовах університетської освіти.

Методи та методика дослідження. Вивчення та аналіз психолого-педагогічних і методичних розробок з питань дослідження для з'ясування стану теоретичного обґрунтування проблеми управління якістю підготовки майбутніх фахівців до професійної діяльності, опрацювання інформації, генерування ідей про розкриття сутності, структури, характеристик і видив (інтегральної, прийняття управлінських рішень, документаційно-інтегративної, прогностично-моніторингової) технологій управління якістю підготовки в університеті, структурнокомпонентного опису різних видів технологій управління; виявлення їх ефективності у вирішенні запланованих навчальних завдань.

Результати та дискусії. Управління якістю підготовки майбутніх учителів до професійної діяльності уможливлює не лише механічне засвоєння навчальної інформації, а творче її опрацювання, знаходження суперечностей, оригінальних ідей, їх оцінку, здатність проводити діалог, полемізувати, дискутувати з іншими учасниками освітнього процесу. Основна мета управління якістю підготовки майбутніх учителів до професійної діяльності - це створення таких умов, які забезпечують розвиток творчих здібностей, креативного саморозвитку, самореалізації та самоствердження їхньої особистості в самостійній професійній діяльності.

Особливість управління якістю підготовки майбутніх учителів до професійної діяльності полягає в тому, що професійне становлення їхньої особистості здійснюється на основі самопізнання, самоуправління своїми діями, залучення їх до різноманітних видів творчої діяльності, за умов проведення постійного аналізу й оцінки власних досягнень, рефлексії результатів. Управлінський аспект якості підготовки студентів стимулює організацію навчальної діяльності, яка має можливості реалізації об'єктивних закономірностей і використання технологічних засобів для перенесення досвіду, що набувають майбутні вчителі 3 успішного виконання професійних функцій, у самостійну педагогічну діяльність. Технологізація управління якістю підготовки майбутніх учителів до професійної діяльності - це система теоретичних положень і рекомендацій, які уможливлюють ефективно організувати управлінські дії викладача з планування, проєктування, реалізації й аналізу об'єктивно необхідних кроків пізнавальної діяльності студентів, що гарантують досягнення прогнозованих результатів у вигляді досвіду творчої педагогічної діяльності. Основні механізми технологізації управління якістю підготовки майбутніх учителів до професійної діяльності необхідно розглядати з урахуванням таких чинників:

- цілеспрямованого створення емоційно сприятливого освітнього середовища, складниками якого $€$ педагогічне управління й освітній процес; 
Серія: Педагогічні науки. - Вип.3. - Бердянськ : БДПУ, 2019. - 453 с.

- формулювання вимог до діяльності й взаємовідносин у системі “викладач - студенти”, що відповідають рівню успішного розв'язання навчальних проблем і завдань;

- поступового ускладнення згідно з можливостями і здібностями студентів вимог до їхньої навчальної діяльності, проте кожного разу рівень вимог відповідає зоні найближчого розвитку їхньої особистості;

- цілеспрямованої роботи з технологізації управління якістю підготовки студентів, ознайомлення їх з технологічними системами, стилями професійної діяльності, розширення форм, методів і засобів навчання, використання різних технологій, які впливають на збагачення їхнього досвіду професійної діяльності;

- $\quad$ надання своєчасної допомоги, корекції дій студентів у набутті ними досвіду професійної діяльності;

- своєчасне ознайомлення їх з напрямами, тенденціями, концепціями модернізації професійної діяльності, розвитком потреби у створенні нового знання, новаторського досвіду й інновацій у професійній сфрері.

Останнім часом увага вчених акцентується на використанні технологій управління інноваційними процесами, у тому числі й у сфері педагогічної діяльності (Л. Даниленко, О. Мармаза, В. Селевко, В. Стадник та ін.). Так, В. Стадник підкреслює, що технологія управління інноваційними процесами охоплює такі методи: опрацювання інформації, прийняття управлінських рішень, генерування інноваційних ідей, створення нового [Стадник, 2006: 79]. Л.Даниленко розробила технологію управління процесом упровадження педагогічних інновацій у навчальний процес, яка мають три складники: концептуальний, змістовий і технологічний [Даниленко, 2004: 310]. О. Мармаза пропонує систему управління інноваційними процесами, яка об'єднує у своєму змісті етапи управлінської діяльності, об'єкти аналізу, управлінські дії та рішення [Мармаза, 2007: 312-314].

Технологізація управління якістю підготовки майбутніх учителів до професійної діяльності - це проєктування педагогічного процесу на діяльнісній основі, що забезпечує необхідні організаційно-педагогічні умови для активної пізнавальної діяльності студентів, раціонального управління їхніми діями з досягнення освітнього результату у вигляді досвіду творчої педагогічної діяльності. У системі управління якістю підготовки майбутніх учителів до професійної діяльності важливе значення має оволодіння ними технологією управління, її складниками (процес педагогічної діяльності, послідовність дій, методи, операції, процедури, інструменти). Оскільки зміст поняття “технологія управління" трактується дослідниками неоднозначно, то студенти повинні чітко розуміти його сутність. Технологія управління розглядається як процес, система знань, сукупність управлінських функцій, процедур і операцій.

Так, на думку І. Кузнєцової, технологія управління - це сукупність знань про виконання процесу управління, вимоги до управлінського персоналу, знань про методи, стан зовнішнього середовища й об'єкта управління, управлінські впливи на досягнення запланованих цілей 
[Кузнєцова, 2009: 59]. Н. Ракша зазначає, що технологія управління - це “певний порядок здійснення процесу управління, який зумовлює послідовність та умови прийняття управлінських рішень і визначає найефективніші методи та інструменти їх упровадження на практиці" [Ракша, 2012: 86]. Е. Смирнов розглядає технологію управління як послідовність виконання управлінських фуннцій (планування, організація, мотивація, контроль) 3 метою оптимізації управлінського впливу для досягнення прогнозованих цілей [Смирнов, 2017]. В. Мосейко трактує технологію управління як “сукупність взаємопов'язаних управлінських процедур, спрямованих на обґрунтування, розробку, приймання управлінських рішень" [2001: 90]. На відміну від В. Мосейко, О. Лебідь розглядає технологію управління як сукупність взаємопов'язаних операцій, що спрямовані на виконання управлінських фрункцій за допомогою використання методів, інструментів, пристроїв [Лебідь, 2012: 302].

Технологія управління якістю підготовки майбутніх учителів до професійної діяльності - це система взаємодії викладача й студентів 3 планування, організації й здійснення освітнього й самоосвітнього процесів, спрямованих на оволодіння обраною професією й підвищення якості університетської освіти. Серед технологій управління значну роль грає документаційно - інтегративна технологія управління якістю підготовки майбутніх учителів до професійної діяльності. Ця технологія виконує функцію документування за допомогою методів аналізу та узагальнення. Її можна представити наглядно (рис. 1):

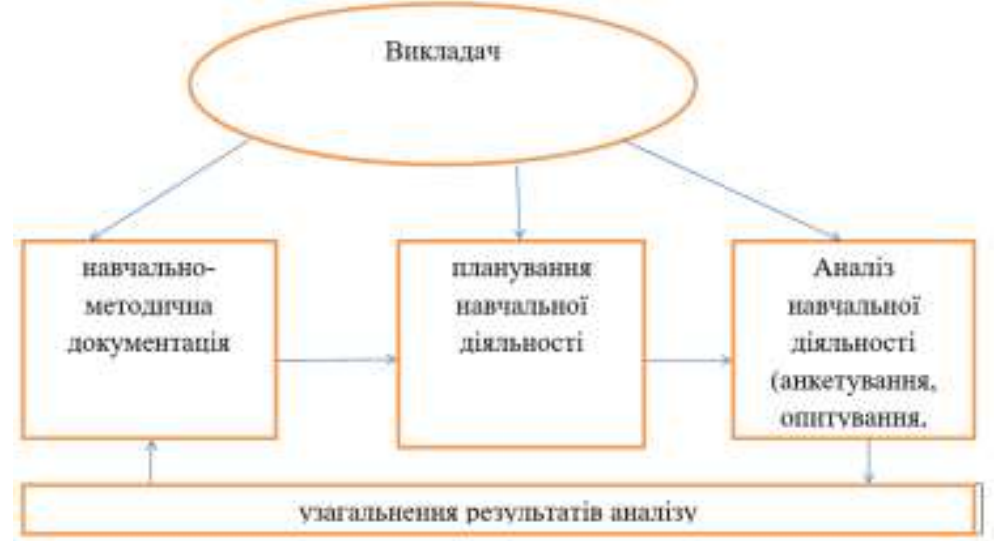

Рис. 1. Модель документально-інтегративної технології

Основні фрункції документально-інтегративної технології: ознайомлення 3 навчально-методичною документацією освітнього процесу; планування діяльності; здійснення критичного аналізу та самооцінки; документування результатів діяльності.

Під час використання цієї технології необхідні вміння правдиво визначати пріоритети використання нормативних документів, що ICV 2018: 77.58 
обумовлюють шляхи розв'язання прогнозованих завдань, досягнення мети і дають змогу моделювати стратегію управління якістю підготовки майбутніх учителів до професійної діяльності.

Різновидом технології управління підготовки майбутніх учителів до професійної діяльності $€$ прогностично-моніторингова технологія управління, основними структурними елементами якої є розробка заходів 3 реалізації навчальної проблеми, повторний моніторинг певного напрямку діяльності, діагностика результатів. У ході використання прогностичномоніторингової технології центр ваги навчальної проблеми переміщується зі формування ії стратегії (планування) на управління процесом упровадження стратегічних змін. Їх мета - розвиток навичок самостійної роботи й активної творчої індивідуальності майбутніх учителів. Роль викладача у процесі використання прогностично-моніторингової технології полягає в: спрямуванні кожного студента на осмислення мети й завдань успішного навчання; пропозиції методів розв'язання прогнозованої мети й завдань; організації самостійної роботи - добір та адаптування методів для ефективних дій, своєчасних навчальних досягнень; створенні організаційно-педагогічних умов для творчої діяльності.

Майбутньому вчителю необхідно усвідомити роль логіки управління в забезпеченні якості навчання, навчитися враховувати ії під час планування, організації й виконання управлінської діяльності. Він має чітко передбачати структуру управління освітнім процесом, яка складається із: визначення складу функцій, які реалізуються в навчанні; добору методів і засобів реалізації управлінських функцій; визначення складу учасників навчання; визначення структури управлінських дій; розподілу завдань; визначення відповідальності за виконання управлінських дій.

Для забезпечення якості підготовки майбутніх учителів використовується технологія прийняття управлінських рішень. Ця технологія має етапний характер і передбачає декілька етапів.

1-й етап - виникнення педагогічної ситуації, яка потребує прийняття рішення (підготовка майбутніх учителів до успішного навчання): а) виникнення проблеми; б) вивчення її стану; в) пошук інформації для її розв'язання;

2-й етап - збір, обробка інформації щодо реалізації успішного навчання;

3-й етап - виявлення альтернативних рішень: а) з'ясування альтернатив;

б) оцінювання альтернатив;

4-й етап - підготовка, оптимізація рішення, вибір альтернативи: а) вибір оптимального варіанта рішення; б) оформлення оптимального варіанта;

5-й етап - прийняття управлінського рішення: а) обговорення проекту; б) затвердження рішення; в) оформлення рішення;

6-й етап - реалізація управлінського рішення та оцінка результатів: а) організація виконання рішення; б) контроль за виконанням рішення; в) оцінка виконання рішення. 
Ця технологія уможливлює оволодіти майбутньому вчителю вміннями прийняття рішень, бачити мету і шляхи досягнення ії, адаптуватися до змін, розвивати творчість, ініціативність, самостійність, установку на самовдосконалення управлінського досвіду.

У педагогічній практиці широко використовується інтегральна технологія, яка стимулює не тільки підвищення якості власних знань, умінь студентів, а й оволодівання технологічним інструментарієм. Структура цієї технології - це блок занять, які об'єднують у собі постійну й змінну частини. Постійна частина занять обумовлюється змістом навчального матеріалу. Змінна частина орієнтується на інформацію зворотного зв'язку в освітньому процесі.

Кожне заняття має організаційну фрорму, яка відповідає різним елементам блоку: вступне повторення. Цей елемент передбачає інтерактивний інформаційний режим, який забезпечується бесідою; вивчення нового матеріалу (основний обсяг) й реалізується у формі лекції, яка дає змогу передати укрупнену одиницю навчальної інформації протягом аудиторного часу; тренінг-мінімум - доведення до автоматизму вміння розв'язувати алгоритмічні задачі; вивчення нового матеріалу (доповнений обсяг) - навчальний матеріал засвоюється студентами на різних рівнях (на рівні усвідомлення й використання, засвоєння стрижневої ідеї, запам'ятовування головного в новому матеріалі) видами контролю; розвиваюче диференційоване закріплення у формі семінару-практикуму, передбачає наявність постійного зворотного зв'язку, поєднання інфрормації про успішність учасників групової роботи і їхні досягнення. Завдання мають різнорівневий характер (мінімум, загальний рівень, високий рівень); узагальнювальне повторення забезпечує студентам можливість цільного, системного сприйняття засвоєного матеріалу; контрольне заняття, яке проводиться у формі трьохрівневого письмового заліку, мета перевірки - отримати об'єктивну інформацію про успішність усього блоку занять; заняття корекції аналіз результатів.

Не менш вагома в набутті майбутніми вчителями досвіду управління якістю пізнавальною діяльністю - когнітивна технологія, побудована на ідеї поопераційного управління пізнавальними діями 3 метою досягнення запланованого результату. Когнітивна технологія має модульну структуру: блок вхідного моніторингу (діагностика вихідного стану студентів); блок вивчення навчального матеріалу (теоретичний блок); процедурний блок (вивчення процедурної інформації). Висновки про вивчення модуля здійснюються за допомогою узагальнювального повторення, контролю й корекції.

Використання різноманітних технологій управління підготовкою майбутніх учителів до професійної діяльності позитивно впливає на динаміку якості університетської освіти і рівень їхнього професіоналізму

Висновки. Використання технологій в управлінні якістю підготовки майбутніх учителів до професійної діяльності стимулюють ресурси навчання, інноваційні активи. Технологізація навчання спрямована на 
розвиток у майбутніх учителів управлінських умінь і лідерських якостей; практичну спрямованість, гармонізацію інформаційної й процесуальної сторін навчання, що забезпечує якість освіти. Технологія управління якістю підготовки майбутніх учителів до професійної діяльності стимулює перехід викладача від «передавача» інформації до викладачаорганізатора. Технологія управління навчанням забезпечує умови для набуття майбутніми вчителями умінням використання теоретичних знань як інструменту практичних дій і набуття досвіду управлінської діяльності, що позитивно впливає на якість їхньої підготовки до самостійної професійної праці.

Подальша розробка технологій управління якістю підготовки майбутніх учителів до професійної діяльності дозволить ефективно виконувати соціальне замовлення на конкурентоспроможні педагогічні кадри. Окрім цього, важливим для практики управління якістю підготовки студентів до професійної діяльності буде дослідження методів оцінювання ефективності та результативності технологій управління освітнім процесом в системі університетської освіти.

\section{Література}

1. Даниленко Л. І. Управління інноваційною діяльністю в загальноосвітніх навчальних закладах: монографія / Л. І. Даниленко. - К. : Міленіум, 2004. - 358 с.

2. Кузнєцова І. Визначення сутності дефініції «технологія управління» / І. Кузнєцова // Вісник Київського національного торговельно-економічного університету, 2009. - № 1. - С. 55-62

3. Лебідь О. Обгрунтування вибору напрямку впровадження технологій управління / О. Лебідь // Економічна стратегія і перспективи розвитку сфери торговлі та послуг: зб. науч. праць/Харк. Держ. Ун-т харчування і торговлі; редкол. О.І.Черевко (відповід ред.) та ін. - 2012. - Вип. 2(16). - С. 302-308

4.Мармаза О.І. Менеджмент в освіті[текст]: Дорожня карта керівника / О.І. Мармаза. - Х.: Видав. Група «Основа», - 2007. - 448с. (Серія «Адміністратору школи»)

5. Мосейко В.О. Управление по изменениям. Концепция внутрифирменного управления в структурах среднего и малого бизнеса: монография / В.О. Мосейко. - Волгоград: Изд-во Волгоград. гос. ун-та, - 2001. $464 c$.

6. Ракша Н.В. Роль інноваційних технологій в управлінні підприємством Н.В. Ракша // Інноваційна економіка. - 2012. - № 9 (35). - С. 86-89

7. Смирнов Э.А. Управлеческие технологии как объект функционального аудита / Э.А. Смирнов. URL: http:// www.cfin.ru/press/ management/ 1998-6/10.shtml (дата звернення: 29.09.2017)

8. Стадник В.В. Інноваційний менеджмент[текст]: Навчальний посібник / В.В. Стадник. - К.: Академвидов, - 2006. - 464c. (Серія «Альма матер»)

\section{References}

1.Danilenko L.I. Management of innovative activity in general educational institutions: monograph / L.I. Danilenko. - K.: Millennium, 2004. - 358 pp.

2.Kuznetsova I. Definition of the essence of the definition of "technology of management" / I. Kuznetsov // Bulletin of the Kiev National University of Trade and Economics, 2009. - No. 1. - P. 55-62. 
3.Lebed O. Justification of the choice of the direction of the implementation of management technologies / O. Lebed // Economic strategy and prospects of trade and services development: Sb. scientific works / Kharkiv. The state Un-t food and trade; rare O.I.Cherevko (correspondent ed.) And others. - 2012. - Exp. 2 (16). - P. 302-308.

4.Marmaza O.I. Management in education [text]: Road map of the head / O.I. Marmaza - X .: Issued. Group "Basis", 2007. - 448p. (Series "Administrator of the School").

5.Moseyko V.O. Change Management. The concept of corporate governance in the structures of medium and small business: monograph / V.O. Moseyko. - Volgograd: Volgograd publishing house. state University, - 2001. - 464p.

6.Raksha N.V. The role of innovative technologies in enterprise management N.V. Raksha // Innovative economy. - 2012. - No. 9 (35). - P. 86-89.

7.Smirnov E.A. Management technologies as an object of functional audit / E.A. Smirnov. URL: http: // www.cfin.ru/press/ management / 1998-6 / 10.shtml (date of the beast: 09/29/2017)

8. Stadnik V.V. Innovation Management [text]: Textbook / VV Stadnik - K : Akademvydov, 2006. - 464p. (Alma Mater series)

\section{АНОТАЦІЯ}

У статті розкриваються сутність технологізації освітнього процесу і ризних видив технології управління якістю підготовки майбутніх учителів до профресійної діяльності в умовах університету. У зазначеному контексті представлено визначення технологізаиіі управління якістю підготовки студентів, схарактеризовані види технологій, їх структура і зміст, механізм використання їх в управлінні навчальним процесом, досягненні прогнозованих результатів як показників якості професійної діяльності. Проблема є в тому, щоб забезпечити засобами технологій управління позитивну дінамику якості підготовки майбутніх учителів до професійної діяльності. Технологізація управління якістю підготовки майбутніх учителів до професійної діяльності розглядається як система теоретичних положень і рекомендацій, які уможливлюють ефективно організувати управлінські дії викладача з планування, проектування, реалізації й аналізу об'єктивно необхідних кроків пізнавальної діяльності студентів, що гарантують успішне досягнення прогнозованих результатів у вигляді досвіду творчої педагогічної діяльності.

У системі управління якістю підготовки майбутніх учителів до професійної діяльності важливе значення має оволодіння ними технологією управління, ї̈ складниками (процес педагогічної діяльності, послідовність дій, методи, операції, процедури, інструменти).

Технологія управління якістю підготовки майбутніх учителів до успішної профресійної діяльності - це система взаємодії викладача й студентів $з$ планування, організації й здійснення освітнього й самоосвітнього процесів, спрямованих на оволодіння обраною професією, формування готовності до успішної діяльності й підвищення якості університетської освіти.

У практиці підготовки майбутніх учителів до професійної діяльності використовуються різноманітні технології управління навчальним процесом, серед яких: документаційно-інтегративна, інтегральна, когнітивна, прийняття управлінських рішень, прогностично-моніторингова технології управління та ін. Технології управління навчанням забезпечує умови для набуття майбутніми вчителями умінням використання теоретичних знань як інструменту практичних дій і досвіду управлінської діяльності, що позитивно впливає на якість їхньої підготовки до самостійної професійної праці.

Ключові слова: управління, технологізація навчального процесу,технології управління, якість професійної діяльності. 